\title{
GH effect on enzyme activity of $11 \beta H S D$ in abdominal obesity is dependent on treatment duration
}

\author{
Helga Á Sigurjónsdóttir, Josef Koranyi, Magnus Axelson ${ }^{1}$, Bengt-Åke Bengtsson and Gudmundur Johannsson \\ Research Centre for Endocrinology and Metabolism, Sahlgrenska University Hospital, 41345 Gothenburg, Sweden and ${ }^{1}$ Department of Clinical \\ Chemistry, Karolinska Hospital, Stockholm, Sweden \\ (Correspondence should be addressed to H Á Sigurjónsdóttir; Email: helga.sigurjonsdottir@medic.gu.se)
}

\begin{abstract}
Objective: In the past years the interaction of GH and 11ßhydroxysteroid dehydrogenase (11ßHSD) in the pathogenesis of central obesity has been suggested.

Design: We studied the effects of 9 months of GH treatment on 11ßHSD activity and its relationship with body composition and insulin sensitivity in 30 men with abdominal obesity, aged 48-66 years, in a randomised, double-blind, placebo-controlled trial.

Methods: Urinary steroid profile was used to estimate 11ßHSD type 1 and 2 (11ßHSD1 and 11ßHSD2) activities. Abdominal s.c. and visceral adipose tissues were measured using computed tomography. Glucose disposal rate (GDR) obtained during a euglycaemic-hyperinsulinaemic glucose clamp was used to assess insulin sensitivity.

Results: In the GH-treated group the 11ßHSD1 activity decreased transiently after 6 weeks $(P<0.01)$ whereas 11ßHSD2 increased after 9 months of treatment $(P<0.05)$. Between 6 weeks and 9 months, GDR increased and visceral fat mass decreased. Changes in 11ßHSD1 correlated with changes in visceral fat mass between baseline and 6 weeks. There were no significant correlations between $11 \beta \mathrm{HSD} 1$ and $11 \beta \mathrm{HSD} 2$ and changes in GDR.

Discussion: The study demonstrates that short- and long-term GH treatment has different effects on $11 \beta H S D 1$ and 11ßHSD2 activity. Moreover, the data do not support that long-term metabolic effects of $\mathrm{GH}$ are mediated through its action on $11 \beta \mathrm{HSD}$.

European Journal of Endocrinology 154 69-74
\end{abstract}

\section{Introduction}

$11 \beta$-Hydroxysteroid dehydrogenase (11ßHSD) is a fundamental regulator of glucocorticoid action. $11 \beta \mathrm{HSD}$ type 1 (11ßHSD1) acts predominantly by generating cortisol from cortisone. This enzyme is primarily found in the liver but has also been found in adipose tissue (1-4). 11ßHSD type 2 (11ßHSD2) has the reverse action and is primarily found in the kidney (5). In past years $11 \beta$ HSD has been suggested to be a possible link in the pathogenesis of essential hypertension, obesity, glucose intolerance and the metabolic syndrome $(3,4,6-10)$.

Using urinary steroid profiles the conversion of cortisone to cortisol has been found to be reduced in adults with abdominal adiposity, indicating reduced activity of $11 \beta H S D 1$ in central adiposity $(9,11)$. This is, however, not a consistent finding in all studies (12). Studies on hypopituitary patients receiving oral glucocorticoid replacement, acromegalic patients withdrawing from octreotide treatment and acromegalic patients treated surgically, indicate that growth hormone (GH) inhibits
$11 \beta \mathrm{HSD} 1$ and thereby decreases the conversion of cortisone to cortisol (increased urinary cortisol/cortisone ratio) $(13-15)$. This is also supported by studies on rats, where $\mathrm{GH}$ and insulin have been found to suppress the conversion of cortisone to cortisol $(15,16)$. On the other hand, in vitro studies of human omental adipose cells demonstrate a dose-dependent inhibition of $11 \beta H S D 1$ by insulin-like growth factor-I (IGF-I) but not GH $(15,16)$. In a small study of hypopituitary patients this was explained as being an inhibitory effect of GH on 11ßHSD1 that was maximal at very low doses and not mediated indirectly by change in circulating insulin (17). In contrast to previous studies, this study found no correlation between the cortisol/cortisone ratio and serum IGF-I concentration. One study demonstrated paradoxically an increase in cortisol/cortisone ratio in adrenocorticotrophin (ACTH)-deficient hypopituitary patients treated with $\mathrm{GH}$ and hydrocortisone replacement therapy but not in hypopituitary patients with sufficient ACTH production (18). The study has been questioned as it depended on overnight urine samples in hypoadrenal 
patients on conventional hydrocortisone replacement therapy, but it implies that the inhibition of $11 \beta \mathrm{HSD} 1$ by $\mathrm{GH}$, with a reduced conversion of cortisone to cortisol, is compensated by a simultaneous inhibition of $11 \beta H S D 2$, with a reduced conversion of cortisol to cortisone (18). If $\mathrm{GH}$ reduces the conversion of cortisol to cortisone, GH deficiency can add to the central adiposity seen in adult GH deficiency and additionally explain some of the lipolytic action of $\mathrm{GH}$ seen in vivo. In insulin-dependent diabetes mellitus, cortisol/cortisone ratio has been found to be reduced, supporting that glucose metabolism influences the activity of $11 \beta H S D ;$ but not all studies agree with this $(19,20)$.

As central adiposity often is coincidental with insulin resistance and there is a strong inverse relationship between visceral fat mass and endogenous $\mathrm{GH}$ secretion, we found it requisite to study the cortisol metabolism in a population with central adiposity and insulin resistance. We have earlier shown that $\mathrm{GH}$ decreases visceral fat and has a biphasic effect on insulin resistance in such a group (21). By analysing $11 \beta H S D$ activity under these circumstances we can study the relationship with central obesity, insulin/glucose metabolism and GH/IGF-I.

In the present study we define $\mathrm{R}_{\text {new }}$, a more precise ratio of cortisol/cortisone as a measure of $11 \beta \mathrm{HSD} 1$ activity, and $\mathrm{Q}$, the quotient for urinary free cortisol and cortisone, as a measure of $11 \beta \mathrm{HSD} 2$ activity.

\section{Patients and methods}

\section{Patients}

Thirty men, aged $58.13 \pm 0.86$ (S.E.m.), with abdominal obesity, were recruited by advertisements in a local newspaper. The inclusion criteria for the study were, 50-65 years of age, body mass index (BMI) of 25$35 \mathrm{~kg} / \mathrm{m}^{2}$, low to normal serum IGF-I concentration, and a waist-to-hip ratio of more than 0.95 . The exclusion criteria were overt diabetes mellitus, a previous cardiovascular event or heart disease.

\section{Study design}

The study was a 9-month, randomised, double-blind, placebo-controlled trial of the administration of recombinant human GH (Genotropin; Pharmacia, Sweden) (21).

The patients were studied as outpatients before, after 6 weeks, and after 9 months of treatment. Physical and laboratory examinations were performed on all visits. Body weight was measured in the morning to the nearest $0.1 \mathrm{~kg}$ wearing indoor clothing. Waist circumference was measured in the standing position with a flexible plastic tape midway between the lower rib margin and the iliac crest, and the hip girth was measured at the widest part of the hip. Blood tests and $24 \mathrm{~h}$ urine collection were obtained for cortisol and cortisone metabolites in all participants at baseline, after 6 weeks and after 9 months.

The daily dose of $\mathrm{GH}$ was $9.5 \mu \mathrm{g} / \mathrm{kg}$ administered s.c. before bedtime. The dose was reduced by half in the event of side-effects. The average dose reduction during the 9 month study was $0.17 \mathrm{mg}$ per day (range -1.7 to 0 ).

\section{Ethics}

Each participant received oral and written information of the study and signed an informed consent before being included into the study. The study was approved by the Ethics Committee at the University of Gothenburg and by the Swedish Medical Products Agency, Uppsala, Sweden.

\section{Body composition}

A five-scan computed tomography technique was used (Philips Tomoscan 350; Mahway, NJ, USA) to measure abdominal adipose tissue. Abdominal s.c. and visceral adipose tissue areas were determined at the level of L4-L5. The tissue areas and anatomical boundaries were determined as described previously (Cowdhury 1994 (22)).

\section{Analytic methods}

A euglycaemic-hyperinsulinaemic glucose clamp was performed after an overnight fast, as previously described (23). The glucose disposal rate (GDR) was measured for $20 \mathrm{~min}$ in steady-state conditions, which were reached after $100 \mathrm{~min}$.

Blood samples were drawn in the morning after an overnight fast. The serum concentration of IGF-I was determined by a hydrochloric acid ethanol extraction RIA using authentic IGF-I for labelling (Nichols Institute Diagnostics, San Juan Capistrano, CA, USA).

Serum insulin was determined by RIA (Phadebas, Pharmacia, Uppsala, Sweden) and blood glucose was measured by the glucose-6-phosphate dehydrogenase method (Kebo Lab, Stockholm, Sweden). Serum haemoglobin A1c (HbA1c) was determined by HPLC (Waters, Millipore AB, Sweden). Serum cortisol was measured by an IRMA (Orion Diagnostica, Orion Corporation Orion Diagnostica, Espoo, Finland).

Steroids in $24 \mathrm{~h}$ urine collections were analysed by using a simplified version of the method previously described (24). Briefly, steroids were extracted from $2.5 \mathrm{ml}$ urine on a Sep-Pak C18 cartridge. Steroid glucuronides were then enzymatically hydrolysed, and following re-extraction on a Sep-Pak C18 cartridge, steroid sulphates were cleaved by solvolysis. Deconjugated steroids were purified on a column of the lipophilic anion exchanger, TEAP-LH-20, in bicarbonate form. The steroids were converted to $O$-methyloxime-trimethylsilyl ether derivatives and after removal of reagents on a 
Lipidex 5000 column, they were analysed by gas chromatography on a Hewlett-Packard 5890 instrument equipped with a fused silica column. Stigmasterol added after hydrolysis was used as internal standard. Using this method essentially all urinary cortisol and cortisone metabolites could be quantified. Therefore, the ratio between the cortisol metabolites tetrahydrocortisol (THF), allotetrahydrocortisol (a-THF) and $\alpha$-cortol and the cortisone metabolites tetrahydrocortisone (THE) and $\alpha$-cortolone, $\mathrm{R}_{\text {new, }}$ was calculated as follows: $(\mathrm{THF}+\mathrm{a}-\mathrm{THF}+\alpha$-cortol $) /(\mathrm{THE}+\alpha$-cortolone $) . \quad$ The minor metabolites $\beta$-cortol and $\beta$-cortolone were not included, since they could not be quantified separately due to similar retention times on the GLC-column. Levels of urinary free cortisol and cortisone were determined by HPLC with UV detection (254 nm) following extraction and purification on a small octylsilanebonded silica column. The quotient $\mathrm{Q}$ was calculated for urinary free cortisol/free cortisone.

\section{Statistical methods}

All the descriptive statistical results are presented as means \pm S.E.M. Within- and between-group comparisons were performed using paired and unpaired Student's $t$-test. Correlations were sought by calculating Fisher's $r$. Before statistical analysis, logarithmic transformation of data with skewed distribution was performed. A twotailed probability value less than 0.05 was considered significant.

\section{Results}

The GH and placebo groups were matched in terms of age, BMI (31.4 \pm 0.7 vs $30.5 \pm 0.8)$, and waist-to-hip ratio $(1.01 \pm 0.01$ vs $1.03 \pm 0.02)$ and did not differ significantly in terms of body composition and glucose metabolism at baseline.

Data on body composition and glucose metabolism have been reported (21). In summary, GH treatment reduced abdominal visceral and s.c. fat mass as compared with placebo treatment without any change in body weight. Blood glucose and plasma insulin levels increased after 6 weeks and returned thereafter to baseline levels, whereas insulin sensitivity decreased after 6 weeks and was improved after 9 months in the GH-treated as compared with the placebo-treated group. The IGF-I levels did not change in the placebo group and increased to an average of $3.30 \pm 0.35$ S.D. above the predicted mean in the GHtreated group after 6 weeks and $1.89 \pm 0.48$ s.D. after 9 months.

\section{Cortisol metabolism}

Serum cortisol concentration decreased after 6 weeks of treatment followed by an increase after 9 months of treatment (Table 1). The enzyme activity of $11 \beta$ HSD1, expressed as $\mathrm{R}_{\text {new }}$, followed the same pattern, with a significant decrease after 6 weeks of GH treatment as compared with placebo (Fig. 1). 11ßHSD2 activity, as quotient $Q$, was unchanged at 6 weeks, but decreased thereafter in the placebo group and increased in the GH-treated group, resulting in a significant betweengroup effect $(P=0.0001)$ after 9 months.

After 6 weeks of $\mathrm{GH}$ treatment, correlations were found between the change in 11ßHSD1 activity, expressed as $R_{n e w}$, and the change in visceral and s.c. abdominal fat (Table 2). After 9 months, the change in $R_{\text {new }}$ correlated with the change in blood glucose, HbAlc levels and serum triglycerides (TGs). Correlations for $\mathrm{R}_{\text {new }}$ and major endpoints of the study are shown in Table 2.

After 6 weeks, the change in $11 \beta$ HSD2 activity, expressed as $Q$, correlated inversely with the change in blood glucose, $\mathrm{HbA1c}$ and serum TG levels. After 9 months, the change in $Q$ showed a trend to correlate with the change in blood glucose, HbAlc and visceral and s.c. adipose fat mass. Between 6 weeks and 9 months, changes in $Q$ correlated with changes in serum TG. Correlation calculations for $\mathrm{Q}$ are given in Table 3.

Table 1 Values for serum cortisol concentration, the calculated ratio of urinary cortisol/cortisone metabolites $\left(\mathrm{R}_{\text {new }}=(\mathrm{a}-\mathrm{THF}+\mathrm{THF}+\right.$ $\alpha$-cortol)/(THE $+\alpha$-cortolone), the $11 \beta \mathrm{HSD} 1$ activity) and the calculated quotient for urinary free cortisol/free cortisone (Q, the $11 \beta \mathrm{HSD} 2$ activity) after $\mathrm{GH}$ treatment or placebo. All values are means \pm S.E.M.

\begin{tabular}{|c|c|c|c|c|c|}
\hline Variable & Baseline & 6 weeks & $\boldsymbol{P}$-value & 9 months & P-value $\neq \#$ \\
\hline \multicolumn{6}{|c|}{ Cortisol (nmol/l) } \\
\hline $\mathrm{GH}$ & $325.6 \pm 19.8$ & $257.8 \pm 19.8$ & $<0.005$ & $318.0 \pm 40.3$ & - \\
\hline Placebo & $350.4 \pm 29.0$ & $306.3 \pm 20.6$ & - & $323.2 \pm 29.5$ & - \\
\hline \multicolumn{6}{|l|}{$\mathrm{R}_{\text {new }}$} \\
\hline $\mathrm{GH}$ & $0.74 \pm 0.02$ & $0.66 \pm 0.02$ & $<0.01$ & $0.71 \pm 0.04$ & - \\
\hline Placebo & $0.87 \pm 0.05$ & $0.88 \pm 0.05$ & - & $0.87 \pm 0.05$ & - \\
\hline $\mathrm{GH}$ & $0.22 \pm 0.02$ & $0.22 \pm 0.01$ & - & $0.25 \pm 0.02$ & $<0.05$ \\
\hline Placebo & $0.38 \pm 0.03$ & $0.35 \pm 0.04$ & - & $0.32 \pm 0.03$ & $<0.01$ \\
\hline
\end{tabular}

†Between baseline value and 6 weeks.

$\ddagger$ Between baseline and 9 months.

\# Difference between groups with $P<0.05$. 


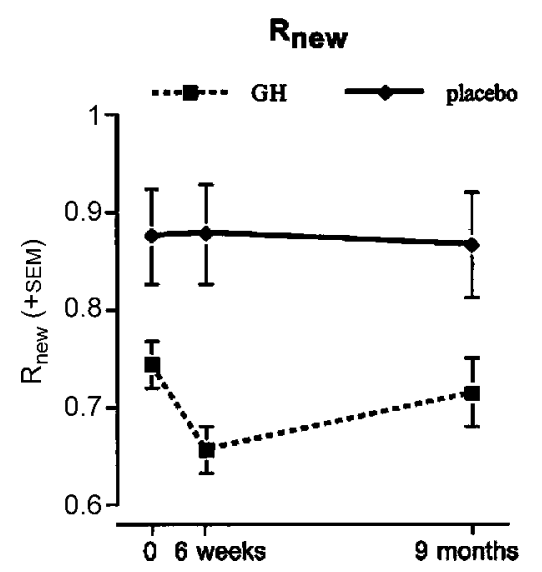

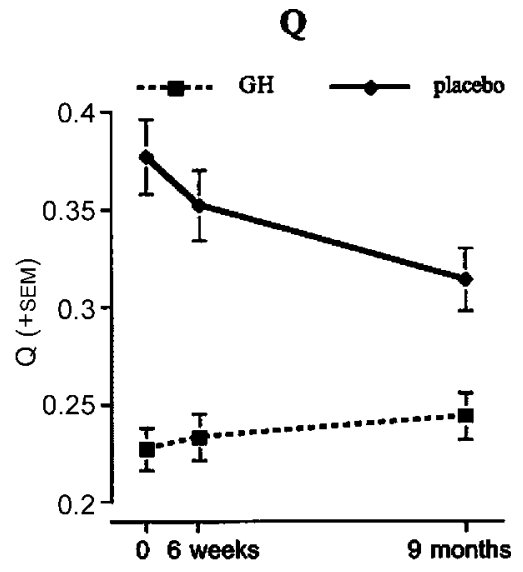

Figure $1 R_{\text {new }}$ is the ratio of urinary cortisol and cortisone metabolites (11 $\beta$ HSD1 activity). $Q$ is the quotient of urinary free cortisol/free cortisone (11ßHSD2 activity). The figure shows the change in $R_{\text {new }}$ and $Q$ (with S.E.M.) after 6 weeks and 9 months of $\mathrm{GH}$ or placebo treatment.
No correlation was found between IGF-I or GDR and measures of $11 \beta$-HSD activity.

\section{Discussion}

In summary, GH treatment of men with abdominal obesity and insulin resistance reduced 11ßHSD1 activity significantly only after 6 weeks and increased 11ßHSD2 activity significantly only after 9 months. The changes observed in $11 \beta \mathrm{HSD}$ correlated with changes in visceral fat mass, blood glucose and $\mathrm{HbAlc}$, but not with measures of insulin sensitivity. These correlations were dependent on duration of GH treatment.

It has been suggested that $Q$ better reflects $11 \beta \mathrm{HSD} 2$ activity than $R_{\text {new }}$, which is used as an indicator of $11 \beta H S D 1$ activity $(25,26)$. Our data show that $R_{\text {new }}$ and $Q$ are affected differently, suggesting that both types of $11 \beta H S D$ respond to $\mathrm{GH}$ treatment. As $\mathrm{R}_{\text {new }}$ is

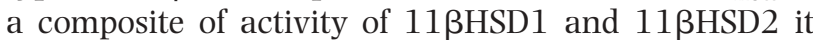
can only be considered to indicate specific changes in the former if the latter is unchanged. As changes in $11 \beta H S D 2$ were observed this might be a confounding factor. 11ßHSD1 activity was reduced after shortterm treatment, leading to decreased conversion of cortisone to cortisol, and the increase in 11ßHSD2 activity became apparent only after more prolonged treatment, causing decreased conversion of cortisol to cortisone.
A previous study supports our finding of $\mathrm{GH}$ treatment influencing both isoenzymes of $11 \beta \mathrm{HSD}$ (18), but this difference in timing of the effect on the different isoenzymes has not been observed before.

A previous study indicates that $11 \beta H S D 1$ may have a role in the pathogenesis of central obesity and another study found alterations in 11ßHSD1 to be associated with general obesity $(26,27)$. We found that abdominal fat mass and visceral fat mass continued to reduce with more prolonged GH treatment that was not accompanied with similar changes in 11ßHSD1 activity. The change in $\mathrm{Q}$, however, showed correlations with the long-term change in central fat mass, suggesting that the change in adipose tissue is related to the change in the activity of $11 \beta \mathrm{HSD} 2$. Although the overall regression analysis demonstrated varying correlations between 11ßHSD activity and central adiposity, our results imply that a stronger relationship exists between the change in $11 \beta H S D$ activity and central adiposity than between the change in $11 \beta \mathrm{HSD}$ activity and insulin sensitivity (28). This is in line with a previous study that found adiposity to be correlated with $11 \beta \mathrm{HSD} 1$ activity but not with insulin sensitivity (29). The associated change in $Q$ and fat mass does not have to have a mechanistic link; it can simply be a parallel phenomenon.

GH/IGF-I-mediated inhibition of $11 \beta H S D 1$ provides a useful means of examining the hypothetical impact of

Table 2 Correlations with changes in $11 \beta H S D 1$ activity $\left(R_{\text {new }}\right)$, in the GH-treated group. Correlations accord to the changes in respective parameter during the same period as $\mathrm{R}_{\text {new. }}$. Blood glucose $=\mathrm{B}$-glucose. Visceral adipose tissue (ViAT45\%) and s.c. adipose tissue (Sc45\%) are measured as per cent of total adipose tissue at the level of L4-L5, indicating central visceral and s.c. fat mass.

\begin{tabular}{|c|c|c|c|c|c|c|c|}
\hline \multirow[b]{2}{*}{ Variable } & \multirow[b]{2}{*}{ Correlation with } & \multicolumn{2}{|c|}{$\Delta \mathrm{B}-6$ weeks } & \multicolumn{2}{|c|}{$\Delta \mathrm{B}-9$ months } & \multicolumn{2}{|c|}{$\Delta 6$ weeks-9 months } \\
\hline & & Fisher's $r$ & $P$-value & Fisher's $r$ & $P$-value & Fisher's $r$ & $P$-value \\
\hline $\mathrm{R}_{\text {new }}$ & $\begin{array}{l}\text { B-glucose } \\
\text { HbA1c } \\
\text { Triglycerides } \\
\text { ViAT45\% } \\
\text { Sc45\% }\end{array}$ & $\begin{array}{r}0.36 \\
0.12 \\
0.28 \\
0.55 \\
-0.55\end{array}$ & $\begin{array}{l}0.2 \\
0.7 \\
0.3 \\
0.03 \\
0.03\end{array}$ & $\begin{array}{r}0.62 \\
0.58 \\
0.63 \\
-0.08 \\
0.08\end{array}$ & $\begin{array}{l}0.009 \\
0.02 \\
0.007 \\
0.8 \\
0.8\end{array}$ & $\begin{array}{r}0.21 \\
-0.07 \\
0.21 \\
0.37 \\
-0.37\end{array}$ & $\begin{array}{l}0.5 \\
0.8 \\
0.4 \\
0.2 \\
0.2\end{array}$ \\
\hline
\end{tabular}

The correlation are with changes in $\mathrm{R}_{\text {new }}$ after $\mathrm{GH}$ treatment during the period between: baseline and 6 weeks $=\Delta \mathrm{B}-6$ weeks; baseline and 9 months $=$ $\Delta \mathrm{B}-9$ months; 6 weeks and 9 months $=\Delta 6$ weeks -9 months. 
Table 3 Correlations with changes in $11 \beta \mathrm{HSD} 2$ activity $(\mathrm{Q})$ in the $\mathrm{GH}$-treated group. Correlations accord to the changes in respective parameter during the same period as $\mathrm{Q}$. Blood glucose = B-glucose.

\begin{tabular}{|c|c|c|c|c|c|c|c|}
\hline \multirow[b]{2}{*}{ Variable } & \multirow[b]{2}{*}{ Correlation with } & \multicolumn{2}{|c|}{$\Delta \mathrm{B}-6$ weeks } & \multicolumn{2}{|c|}{$\Delta B-9$ months } & \multicolumn{2}{|c|}{$\Delta 6$ weeks -9 months } \\
\hline & & Fisher's $r$ & $P$-value & Fisher's $r$ & $P$-value & Fisher's $r$ & $P$-value \\
\hline$Q$ & $\begin{array}{l}\text { B-glucose } \\
\text { HbA1c } \\
\text { Triglycerides }\end{array}$ & $\begin{array}{r}-0.53 \\
-0.60 \\
0.57\end{array}$ & $\begin{array}{l}0.04 \\
0.01 \\
0.02\end{array}$ & $\begin{array}{l}-0.48 \\
-0.44 \\
-0.09\end{array}$ & $\begin{array}{l}0.06 \\
0.09 \\
0.8\end{array}$ & $\begin{array}{l}0.29 \\
0.02 \\
0.57\end{array}$ & $\begin{array}{l}0.3 \\
1.0 \\
0.02\end{array}$ \\
\hline
\end{tabular}

The correlations are with changes in $\mathrm{Q}$ after $\mathrm{GH}$ treatment during the period between: baseline and 6 weeks $=\Delta \mathrm{B}-6$ weeks; baseline and 9 months $=$ $\Delta \mathrm{B}-9$ months; 6 weeks and 9 months $=\Delta 6$ weeks -9 months.

abnormal tissue-specific glucocorticoid metabolism in determining visceral adiposity. One of the major findings of the present study may be that such a mechanism is quantitatively minor in viscerally adipose but otherwise normal subjects. The change in 11ßHSD1 activity, expressed as $R_{\text {new }}$, correlated with visceral fat mass after 6 weeks of treatment. The decrease in serum cortisol and $R_{\text {new }}$ after 6 weeks was only transient, while visceral fat mass was found to decrease continuously from the beginning of GH treatment. This suggests that the longterm effect of $\mathrm{GH}$ on visceral fat mass is not mediated through its action on glucocorticoid metabolism. The possibility remains, however, that the reduction in $\mathrm{R}_{\text {new }}$ in the initial phase of treatment augments the lipolytic action of $\mathrm{GH}$ and counteracts the diabetogenic action of GH during more prolonged treatment, as indicated in the regression analysis. The transient change in $R_{\text {new }}$ and sustained change in visceral fat mass in our study is, however, contradictory to the findings in acromegaly, where a major and sustained reduction in 11ßHSD1 activity has been observed along with sustained reduction in visceral fat and no change in $11 \beta \mathrm{HSD} 2$ activity $(Q)(14,25,30)$. Our results may be explained by the duration of treatment that is much longer than the $6-8$ week treatment previously reported $(14,30)$.

It has been argued that changes in cortisol-binding globulin might explain changes in circulating cortisol levels after GH replacement therapy, but results have been inconsistent $(31,32)$.

Tomlinson et al. showed that $\mathrm{GH}$ in a dose of $0.4 \mathrm{mg}$ daily, inhibited 11ßHSD1 without affecting fat mass in men and women with simple obesity (33). Our dose was higher and the metabolic effects of treatment more marked, in a study containing only men with abdominal obesity. The difference in effect can thus be dose dependent as well as gender dependent, as we both find the type 1 and 2 of the 11ßHSD to be affected by GH treatment.

We conclude that the effect of GH on 11ßHSD is different after short-term and long-term treatment. This may help to explain some paradoxical results from previous studies on GH. We could also demonstrate that GH has an effect on both 11ßHSD1 and $11 \beta H S D 2$. We were not able to show parallel statistically significant changes between 11ßHSD activity, insulin sensitivity and visceral fat mass during longterm GH treatment. We therefore find it unlikely that the key metabolic changes of $\mathrm{GH}$ are mediated through changes in glucocorticoid metabolism. It is still tempting to speculate that the short-term changes seen in $11 \beta$ HSD1 may help to mediate some of the beneficial effects of $\mathrm{GH}$ in fat mass and fat distribution.

\section{Acknowledgements}

The personnel at the Medical Research Centre, the Clinical Metabolic Laboratory and the Research Centre for Endocrinology and Metabolism are gratefully acknowledged for their skilful technical support. The placebo/rhGH preparations were kindly provided by Pharmacia \& Upjohn, Stockholm, Sweden.

\section{References}

1 Tannin G, Agarwal A, Monder C, New M \& White P. The human gene for 11 betahydroxysteroid dehydrogenase. Structure, tissue distribution and chromosomal localization. Journal of Biological Chemistry $199126616653-16658$.

2 Yang K, Khalil MW, Strutt BJ \& Killinger DW. 11 beta-hydroxysteroid dehydrogenase 1 activity and gene expression in human adipose stromal cells: effect on aromatase activity. Journal of Steroid Biochemistry and Molecular Biology 199760 247-253.

3 Bujalska IJ, Kumar S \& Stewart PM. Does central obesity reflect 'Cushings's disease of the omentum'? Lancet $1997 \mathbf{3 4 9}$ $1210-1213$.

4 Katz JR, Mohammed-Ali V, Wood PJ, Yudkin JS \& Coppack SW. An in vivo study of the cortisol-cortisone shuttle in subcutaneous abdominal adipose tissue. Clinical Endocrinology 199950 63-68.

5 Walker B, Campbell J, Williams B \& Edwards C. Tissue-specific distribution of the NAD + -dependent isoform of 11 beta-hydroxysteroid dehydrogenase. Endocrinology $1992131970-972$.

6 Donovan SJ. 11 beta-Hydroxysteroid dehydrogenase: a link between the dysregulation of cortisol metabolism and hypertension. British Journal of Biomedical Science 199956 215-225.

7 Sigurjonsdottir HA, Manhem K, Axelson M \& Wallerstedt S. Subjects with essential hypertension are more sensitive to the inhibition of 11 beta-HSD by liquorice. Journal of Human Hypertension 200317 125-131.

8 vanUum SH, Hermus AR, Smits P, Thien T \& Lenders JW. The role of 11 betahydroxysteroid dehydrogenase in the pathogenesis of hypertension. Cardiovascular Research 199838 16-24.

9 Andrew R, Phillips DIW \& Walker BR. Obesity and gender influence cortisol secretion and metabolism in man. Journal of Clinical Endocrinology and Metabolism 199883 1806-1809. 
10 Andrews RC, Herlihy O, Livingstone DEW, Andrew R \& Walker BR. Abnormal cortisol metabolism and tissue sensitivity to cortisol in patients with glucose intolerance. Journal of Clinical Endocrinology and Metabolism $2002875587-5593$.

11 Rask E, Walker BR, Söderberg S, Livingstone DE, Eliasson M, Johnson $\mathrm{O}$, Andrew R \& Olsson T. Tissue-specific changes in peripheral cortisol metabolism in obese women: increased adipose 11 beta-hydroxysteroid dehydrogenase type 1 Activity. Journal of Clinical Endocrinology and Metabolism 200287 3330-3336.

12 Tomlinson JW, Shina B, Bujalska I, Hewison M \& Stewart PM. Expression of 11 beta-hydroxysteroid dehydrogenase type 1 in adipose tissue is not increased in human obesity. Journal of Clinical Endocrinology and Metabolism 200287 5630-5635.

13 Weaver JU, Thaventhiran L, Noonan K, Burrin JM, Taylor NF, Norman MR \& Monson JP. The effect of growth hormone replacement on cortisol metabolism and glucocorticoid sensitivity in hypopituitary adults. Clinical Endocrinology $1994 \mathbf{4 1} 639-648$.

14 Gelding SV, Taylor NF, Wood PJ, Noonan K, Weaver JU, Wood DF \& Monson JP. The effect of growth hormone replacement therapy on cortisol-cortisone interconversion in hypopituitary adults: evidence for growth hormone modulation of extrarenal 11 betahydroxysteroid dehydrogenase activity. Clinical Endocrinology $1998 \mathbf{4 8} 153-162$.

15 Moore JS, Monson JP, Kaltsas G, Putignano P, Wood PJ, Sheppard MC, Besser GM, Taylor NF \& Stewart PM. Modulation of 11 beta-hydroxysteroid dehydrogenase isozymes by growth hormone and insulin-like growth factor: in vivo and in vitro studies. Journal of Clinical Endocrinology and Metabolism $1999 \mathbf{8 4}$ $4172-4177$.

16 Liu Y-J, Nakagawa Y, Nasuda K, Saegusa H \& Igarashi Y. Effect of growth hormone, insulin and dexamethasone on 11-betahydroxysteroid dehydrogenase activity on a primary culture of rat hepatocytes. Life Sciences $199659227-234$.

17 Toogood AA, Taylor NF, Shalet SM \& Monson JP. Modulation of cortisol metabolism by low-dose growth hormone replacement in elderly hypopituitary patients. Journal of Clinical Endocrinology and Metabolism $2000 \mathbf{8 5} 1727-1730$.

18 Walker BR, Andrew R, MacLeod KM \& Padfield PL. Growth hormone replacement inhibits renal and hepatic 11 beta-hydroxysteroid dehydrogenases in ACTH-deficient patients. Clinical Endocrinology $1998 \mathbf{4 9} 257-263$.

19 Dullaart RPF, Ubels FL, Hoogenberg K, Smit AJ, Pratt JJ, Muntinga JHJ, Sluiter WJ \& Wolthers BG. Alterations in cortisol metabolism in insulin-dependent diabetes mellitus: relationship with metabolic control and estimated blood volume and effect of angiotensin-converting enzyme inhibition. Journal of Clinical Endocrinology and Metabolism $1995 \mathbf{8 0} 3002-3008$.

20 Kerstens MN, Riemens SC, Sluiter WJ, Pratt JJ, Wolthers BG \& Dullaart RPF. Lack of relationship between 11 beta-hydroxysteroid dehydrogenase setpoint and insulin sensitivity in the basal state and after $24 \mathrm{~h}$ of insulin infusion in healthy subjects and type 2 diabetic patients. Clinical Endocrinology 200052 403-411.

21 Johannsson G, Mårin $\mathrm{P}$, Lönn L, Ottosson M, Stenlöf K, Björntorp P, Sjöström L \& Bengtsson B-A. Growth hormone treatment of abdominally obese men reduces abdominal fat mass, improves glucose and lipoprotein metabolism, and reduces diastolic blood pressure. Journal of Clinical Endocrinology and Metabolism $1997 \mathbf{8 2} 727-734$.

22 Cowdhury B, Sjöström L, Alpsten M, Konstanty J, Kvist H \& Löfgren R. A multicompartment body composition technique based on computed tomography. Internal Journal of Obesity 1994 $18219-234$.

23 DeFronzo RA, Tobin JD \& Andres R. Glucose clamp technique: a method for quantifying insulin secretion and resistance. American Journal of Physiology 1979237 E214-E223.

24 Axelson M, Sahlberg BL \& Sjövall J. Analysis of profiles of conjugated steroids in urine by non-exchange separation and gas chromatography-mass spectrometry. Journal of Chromatography 1981 $224355-370$.

25 Best R \& Walker BR. Additional value of measurement of urinary cortisone and unconjugated cortisol metabolites in assessing the activity of 11 betahydroxysteroid dehydrogenase in vivo. Clinical Endocrinology $1997 \mathbf{4 7} 231-236$.

26 Palermo M, Shackleton CHL, Mantero F \& Stewart PM. Urinary free cortisone and the assessment of 11 beta-hydroxysteroid dehydrogenase activity in man. Clinical Endocrinology $1996 \mathbf{4 5}$ 605-611.

27 Stewart PM, Boulton A, Kumar S, Clark PMS \& Shackleton CHL. Cortisol metabolism in human obesity: impaired cortisone cortisol conversion in subjects with central adiposity. Journal of Clinical Endocrinology and Metabolism 199984 1022-1027.

28 Westerbacka J, Yki-Jarvinen H, Vehkavaara S, Hakkinen AM, Andrew R, Wake DJ, Seckl JR \& Walker BR. Body fat distribution and cortisol metabolism in healthy men: enhanced 5betareductase and lower cortisol/cortisone metabolite ratios in men with fatty liver. Journal of Clinical Endocrinology and Metabolism $2003 \mathbf{8 8} 4924-4931$.

29 Wake DJ, Rask E, Livingstone DE, Soderberg S, Olsson T \& Walker BR. Local and systemic impact of transcriptional up-regulation of 11beta-hydroxysteroid dehydrogenase type 1 in adipose tissue in human obesity. Journal of Clinical Endocrinology Metabolism $2003 \mathbf{8 8} 3983-3988$.

30 Trainer P, Drake W, Perry L, Taylor N, Besser G \& Monson J. Modulation of cortisol metabolism by the growth hormone receptor antagonist pegvisomant in patients with acromegaly. Journal of Clinical Endocrinology and Metabolism $2001862989-2992$.

31 Isidori A, Kaltsas G, Perry L, Burrin J, Besser G \& Monson J. The effect of growth hormone replacement therapy on adrenal androgen secretion in adult onset hypopituitarism. Clinical Endocrinology $2003 \mathbf{5 8} 601-611$.

32 Rodriguez-Arnao J, Perry L, Besser G \& Ross R. Growth hormone treatment in hypopituitary GH deficient adults reduces circulating cortisol levels during hydrocortisone replacement therapy. Clinical Endocrinology $1996 \mathbf{4 5} 33-37$.

33 Tomlinson JW, Crabtree N, Clark PMS, Holder G, Toogood AA, Shackleton CHL \& Stewart PM. Low-dose growth hormone inhibits 11 beta-hydroxysteroid dehydrogenase type 1 but has no effect upon fat mass in patients with simple obesity. Journal of Clinical Endocrinology and Metabolism 200388 2113-2118.

Received 12 August 2005

Accepted 26 September 2005 